\title{
Pelatihan Penggunaan Media Pembelajaran Interaktif Sistem Informasi Geografis Mata Pelajaran Pemrograman Web
}

\author{
Aris Sudianto*1, Imam Fathurrahman ${ }^{2}$, Hamzan Ahmadi ${ }^{3}$, Mahpuz $^{4}$, Muhammad \\ Sadali $^{5}$, Indra Gunawan ${ }^{6}$, Bq.Andriska Candra P $^{7}$, Muhammad Wasil ${ }^{8}$, L.Kerta \\ Wijaya $^{9}$, Suhartini ${ }^{10}$, Harianto ${ }^{11}$ \\ sudianto166@gmail.com*1 \\ 1,2,3,4,5,6,7,8,9,10,11 Teknik Informatika, Universitas Hamzanwadi
}

Received: 29 September 2021 Accepted: 06 December 2021 Online Published: 30 December 2021 DOI: 10.29408/ab.v2i2.4029

\begin{abstract}
Abstrak: Media pembelajaran interaktif merupakan salah satu alat bantu dalam proses pembelajaran. Dengan media pembelajaran interaktif akan membantu siswa dalam memahami materi pembelajaran dengan lebih baik, terutama mata pelajaran yang membutuhkan praktik untuk lebih memahami teori yang diajarkan. Mata pelajaran pemrograman web pada sekolah kejuruan merupakan salah satu mata pelajaran yang memiliki banyak praktikum. Oleh karena itu, untuk mendukung tersampaikannya materi pelajaran tersebut dibutuhkan media pembelajaran interaktif yang baik dan sesuai dengan kebutuhan siswa. PKM ini bertujuan untuk memberikan pelatihan penggunaan media pembelajaran interaktif Sistem Informasi Geografis (GIS) berbasis web yang telah dikembangkan, sehingga siswa lebih paham mengenai perancangan aplikasi berbasis web. Kegiatan ini dilaksanakan di SMKN 1 Selong, dengan peserta berasal dari jurusan Rekayasa Perangkat Lunak berjumlah 25 orang. Kegiatan berlangsung selama 4 bulan. Metode yang digunakan yaitu ceramah dan praktik langsung tentang rekayasa perangkat lunak berbasis WEB dengan narasumber dosen program studi Teknik Informatika, Universitas Hamzanwadi. Materi yang disampaikan berupa langkah-langkah membuat perangkat lunak sederhana dengan memanfaatkan teknologi yang sudah ada dan melihat beberapa contoh yang sudah disiapkan sebelumnya oleh narasumber untuk dapat digunakan oleh siswa. Untuk metode ini menggunakan perangkat komputer dengan jaringan lokal. Hasil kegiatan menunjukkan siswa siswi mampu menguasai teknik dasar untuk suatu perangkat lunak berbasis WEB dan siswa juga mampu membuat aplikasi berbasis WEB sederhana dengan menerapkan konsep analisis sistem yang baik.
\end{abstract}

Kata kunci: Media Pembelajaran; Rekayasa Perangkat Lunak, Sistem Informasi Geografis;

\begin{abstract}
Interactive learning media is one of the tools in the learning process. With interactive learning media, it will help students understand the learning material better, especially subjects that require practice to better understand the theory being taught. Web programming subjects in vocational schools are one of the subjects that have a lot of practicums. Therefore, to support the delivery of the subject matter, good interactive learning media are needed and are following the needs of students. This PKM aims to provide training on the use of web-based interactive learning media for Geographic Information Systems (GIS) that have been developed so that students understand more about designing web-based applications. This activity was carried out at SMKN 1 Selong, with 25 participants from the Software Engineering department. The activity lasted for 4 months. The method used is lectures and direct practice on WEB-based software engineering with lecturers from the Informatics Engineering study program, Hamzanwadi University. The material presented is in the form of steps to make simple software by utilizing existing technology and seeing some examples that have been prepared previously by the resource person to be used by students. For this method use a computer with a local network. The results of the activity show that students can master basic techniques for WEB-based software and students are also able to make simple WEB-based applications by applying the concept of good system analysis.
\end{abstract}

Keywords: Interactive Learning Media; Geographic Information Systems; Software Engineering 
Sudianto, A., Fathurrahman I., Ahmadi, H., Mahpuz, M., Sadali, M., Gunawan, I., Pemana, B. A. C., Wasil, M., Wijaya, L. K., Suhartini, S., Harianto, H. (2021). Pelatihan penggunaan media pembelajaran interaktif Sistem Informasi Geografis mata pelajaran Pemrograman Web. ABSYARA: Jurnal Pengabdian Pada Masyarakat, 2(2), 170-177. doi:10.29408/ab.v2i2.4029

\section{PENDAHULUAN}

Geographic Information System (GIS) atau Sistem Informasi Geografis (SIG) adalah salah satu teknologi yang berkembang untuk memungkinkan orang memecahkan banyak masalah geografis dengan cepat, efektif dan mudah dengan kemampuan untuk membuat analisis, terutama analisis lokasi yang dikombinasikan dengan sistem database tradisional (Okan, 2012). Selain itu menurut Chang (2016) SIG merupakan sistem komputer untuk menangkap, menyimpan, query, menganalisis, dan menampilkan data geospasial. SIG juga mampu mengatur, menganalisis, dan menggabungkan data yang hasil akhirnya dapat dijadikan acuan untuk mengambil keputusan dari suatu masalah yang berkaitan dengan geografi (Sudianto, dkk., 2020).

Dalam Meningkatkan mutu Pendidikan, pemerintah Indonesia sudah memberikan perhatian khusus terkait perkembangan ilmu pengetahuan dengan penerapan teknologi yang semakin cepat. Media pembelajaran menjadi sangat penting untuk digunakan oleh guru dalam memberikan materi yang dapat membuat siswa menjadi lebih cepat dalam memahami setiap materi (Sudianto \& Samsu, 2019). Penerapan hasil penelitian ini merupakan salah satu cara yang ditempuh untuk dapat meningkatkan minat bagi siswa dalam belajar, hal ini dikarenakan hasil produk yang sudah jadi dan siap untuk digunakan, sehingga siswa dapat mengetahui seperti apa penerapan dari teknologi rekayasa perangkat lunak yang sebenarnya dalam kehidupan sehari-hari (Sudianto, dkk., 2021; Wulandari, dkk., 2015)

SMK Negeri 1 Selong merupakan sekolah kejuruan yang telah lama menjadi mitra mahasiswa Fakultas Teknik, Universitas Hamzanwadi dalam pelaksanaan kegiatan Kerja Praktik. Dari hasil kegiatan tersebut didapatkan data bahwa siswa kurang mampu memahami peran teknologi informasi dan komunikasi dalam proses pembelajaran. Hal ini dikarenakan siswa lebih cendrung memanfaatkan teknologi informasi untuk hiburan dan social media saja.

Dengan penerapan produk hasil penelitian yang sudah siap untuk digunakan dapat dijadikan sebagai contoh untuk siswa dalam membuat perangkat lunak baru, terlebih lagi mata pelajaran yang diajarkan disekolah juga mengarah ke arah teknologi perangkat lunak, namun masih sebatas contoh sederhana saja, untuk itu dengan memberikan pelatihan kepada siswa dalam membuat perangkat lunak yang dapat digunakan di kehidupan sehari - hari diharapkan dapat membuat siswa menjadi lebih semangat dalam belajar, dan juga hasil produk yang dihasilkan dalam penelitian benar- benar dapat digunakan dengan baik dan dapat diterapkan sebagai bahan media pembelajaran bagi siswa siswi di SMK Negeri 1 Selong Kabupaten Lombok Timur. Penerapan Produk Hasil Penelitian Sistem Informasi Geografis (GIS) Untuk Pemetaan Kerajinan Kain Tenun Dan Gerabah Berbasis Web merupakan salah satu langkah yang diambil untuk dapat memberikan pemahaman kepada siswa terhadap cara merancang aplikasi secara nyata dan dampaknya terhadap masyarakat (Sudianto \& Sadali, 2018; Setiadi, dkk., 2015).

\section{METODE PELAKSANAAN}

\section{Waktu dan Lokasi}

PKM dilaksanakan dari bulan Mei - Oktober 2021. Kegiatan PKM ini dilakukan secara bertahap dengan skema 1 Bulan yaitu bulan Mei 2021 untuk pelaksanaan pelatihan penerapan 
Sudianto, A., Fathurrahman I., Ahmadi, H., Mahpuz, M., Sadali, M., Gunawan, I., Pemana, B. A. C., Wasil, M., Wijaya, L. K., Suhartini, S., Harianto, H. (2021). Pelatihan penggunaan media pembelajaran interaktif Sistem Informasi Geografis mata pelajaran Pemrograman Web. ABSYARA: Jurnal Pengabdian Pada Masyarakat, 2(2), 170-177. doi:10.29408/ab.v2i2.4029

produk hasil penelitian dengan memaparkan materi secara teori dan praktik kepada siswa siswi di SMK Negeri 1 Selong mengenai konsep web dinamis, kemudian untuk 4 Bulan berikutnya dari bulan Juni sampai September 2021 dilaksanakan dengan skema pemantauan hasil/monitoring hasil oleh dosen program studi. Kegiatan laksanakan di SMK Negeri 1 Selong, Jurusan Rekayasa Perangkat Lunak dengan jumlah peserta sebanyak 25 orang.

\section{Prosedur pelaksanaan}

Tahapan prosedur pelaksanaan dalam kegiatan ini dapat dilihat pada gambar berikut ini:

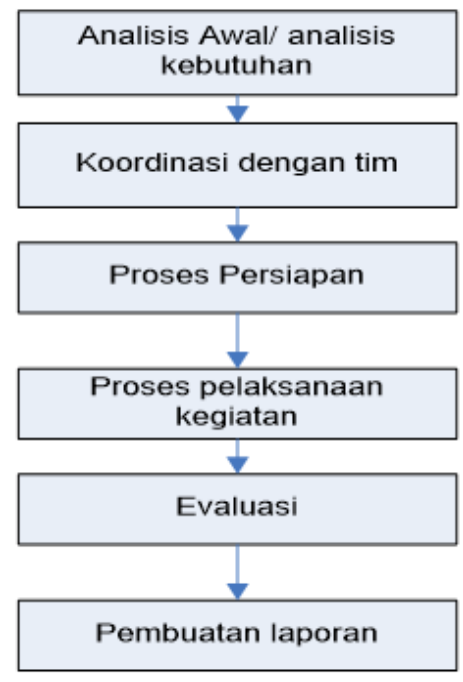

Gambar 1. Tahapan Prosedur Pelaksanaan Kegiatan PKM (Suhartini, dkk., 2021)

Pada tahap pertama, analisis kebutuhan dilakukan untuk mengetahui kebutuhan dalam melaksanakan kegiatan pengabdian, dari mulai penentuan mitra, analisis kebutuhan sarana dan prasaran, biaya, dan lain sebagainya. Setelah itu tim akan berkoordinasi dan mempersiapkan segala kebutuhan yang telah didapatkan dari analisis kebutuhan.

PKM dimulai dari tanggal 3 Mei 2021, dimulai dengan pembukaan oleh tim dari program studi Teknik Informatika Fakultas Teknik Universitas Hamzanwadi bersama dengan ketua jurusan Teknik komputer dan Informatika SMK Negeri 1 Selong. Dalam pelaksanaannya kegiatan ini dilakukan secara bertahap dengan skema 1 bulan pertama untuk pendampingan dan pemberian materi secara teori dan praktik, bulan berikutnya dilakukan dengan pemantauan hasil/monitoring hasil. Monitoring dan Evaluasi dilakukan di setiap bulan selama kegiatan berlangsung, agar tim dapat mengetahui perkembangan siswa dalam mengikuti kegiatan. Evaluasi dinilai berdasarkan keberhasilan siswa dalam menyelesaikan soal-soal yang diberikan. Kemudian hasil tersebut akan dijadikan bahan dikusi oleh tim dan dibuat laporan (Kholisho, 2021). Adapun metode pelaksanaan pelatihan dilakukan melalui 2 cara yaitu:

1. Ceramah

Penyampaian materi tentang rekayasa perangkat lunak berbasis WEB oleh tim PKM yang merupakan narasumber. 
Sudianto, A., Fathurrahman I., Ahmadi, H., Mahpuz, M., Sadali, M., Gunawan, I., Pemana, B. A. C., Wasil, M., Wijaya, L. K., Suhartini, S., Harianto, H. (2021). Pelatihan penggunaan media pembelajaran interaktif Sistem Informasi Geografis mata pelajaran Pemrograman Web. ABSYARA: Jurnal Pengabdian Pada Masyarakat, 2(2), 170-177. doi:10.29408/ab.v2i2.4029

\section{Praktik}

Praktik perangkat lunak berbasis web sederhana dengan memanfaatkan teknologi yang sudah ada dan melihat beberapa contoh yang sudah disiapkan sebelumnya oleh narasumber untuk dapat digunakan oleh siswa. Untuk metode ini menggunakan perangkat komputer dengan jaringan lokal.

Melalui kegiatan PKM ini, diharapkan siswa dapat merasakan besarnya manfaat penggunaan teknologi dalam proses pembelajaran. Siswa juga mampu membuat aplikasi web dinamis sederhana sehingga dapat mendukung siswa ketika melaksanakan ujian praktik.

\section{HASIL DAN PEMBAHASAN HASIL}

Dalam pelaksanaannya, kegiatan dilaksanakan selama 5 bulan yang dilakukan secara bertahap dengan skema 1 bulan pelaksanaan pelatihan penerapan produk hasil penelitian dengan memaparkan materi secara teori dan praktik kepada siswa - siswi di SMK Negeri 1 Selong mengenai konsep web dinamis, kemudian untuk 4 Bulan berikutnya di laksanakan dengan skema pemantauan hasil/monitoring hasil oleh dosen program studi, yang dalam pelaksanaannya dilaksanakan di sore hari sebagai materi tambahan bagi siswa.

Pelaksanaan PKM ini dilaksanakan mulai dari bulan Mei - Oktober 2021, yang bertempat di Jurusan Teknik Informatika dan Komputer Bidang Rekayasa Perangkat Lunak SMK Negeri 1 Selong, dikarenakan kondisi sedang mewabahnya virus Corona membuat pelaksanaan kegiatan pengabdian masyarakat menjadi sedikit kesulitan, dikarenakan pada hari-hari tertentu siswa harus dibagi menjadi 2 sesi untuk mengurangi jumlah perkumpulan siswa. Namun demikian tidak menyurutkan minat siswa untuk belajar dan juga tidak menurunkan semangat dari dosen program studi teknik informatika untuk memberikan materi. Dalam pelaksanaan kegiatan pengabdian kepada masyarakat ini dilaksanakan pada sore hari sebagai materi tambahan bagi siswa, dikarenakan di pagi hari siswa harus melaksanakan kegiatan belajar seperti biasa.

Pada hari pertama dilakukan pembukaan serta persiapan tempat dan peralatan yang dibutuhkan, pemberian arahan oleh narasumber terkait pentingnya teknologi dan rekayasa perangkat lunak untuk kebutuhan masyarakat luas yang disampaikan oleh dosen dari program studi Teknik Informatika Fakultas Teknik Universitas Hamzanwadi. Pada hari kedua sampai hari ke 15 dilakukan praktik pembuatan sistem perangkat lunak berbasis web dengan menggunakan tool yang juga digunakan belajar oleh siswa, sehingga membuat siswa tidak merasa kesulitan dalam belajar. Pada tahapan ini materi di berikan oleh beberapa dosen sebagai narasumbernya.

Hari ke 16 sampai hari ke 25 siswa siswi jurusan rekayasa perangkat lunak yang telah mengikuti pelatihan di hari-hari sebelumnya harus menghasilkan suatu produk perangkat lunak yang dapat digunakan dengan mengambil tema bebas sesuai dengan tren yang sedang berkembang sekarang ini, di hari terakhir di bulan pertama, siswa siswi yang telah berhasil membuat perangkat lunak harus mempresentasikan hasil karya inovasinya ke pada para narasumber untuk kemudian diberikan penilaian. Hasil yang terbaik yang dihasilkan oleh siswa dalam kegiatan ini akan diberikan reward berupa hadiah - hadiah sehingga kegiatan menjadi lebih hidup dan siswa - siswi semangat mengikuti kegiatan. 
Sudianto, A., Fathurrahman I., Ahmadi, H., Mahpuz, M., Sadali, M., Gunawan, I., Pemana, B. A. C., Wasil, M., Wijaya, L. K., Suhartini, S., Harianto, H. (2021). Pelatihan penggunaan media pembelajaran interaktif Sistem Informasi Geografis mata pelajaran Pemrograman Web. ABSYARA: Jurnal Pengabdian Pada Masyarakat, 2(2), 170-177. doi:10.29408/ab.v2i2.4029

Kegiatan pelatihan ini dilaksanakan di laboratorium Rekayasa perangkat Lunak SMK Negeri 1 Selong, kegiatan ini diikuti oleh 25 peserta dengan materi pembuatan aplikasi WEB dengan contoh kasus Inventaris barang. Untuk kegiatan ini sebelumnya telah dipaparkan materinya oleh koordinator program studi Teknik Informatika.

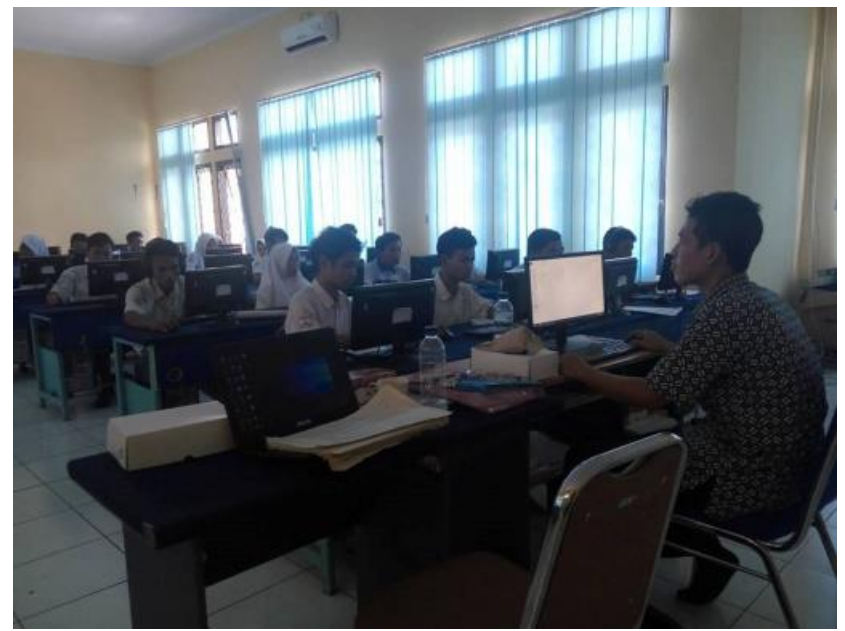

Gambar 1. Pelaksanaan Pelatihan Kepada Siswa RPL

Kegiatan pelatihan pembuatan Web dinamis seperti yang terlihat pada gambar 2 merupakan inti dari kegiatan Penerapan Produk Hasil Penelitian Sistem Informasi Geografis (GIS) Untuk Pemetaan Kerajinan Kain Tenun Dan Gerabah Berbasis Web Sebagai Media Pembelajaran Pada Mata Pelajaran Pemrograman Web di SMK Negeri 1 Selong. Pada kegiatan tersebut materi pelatihan disampaikan oleh koordinator program studi Teknik Informatika selama 3 jam.
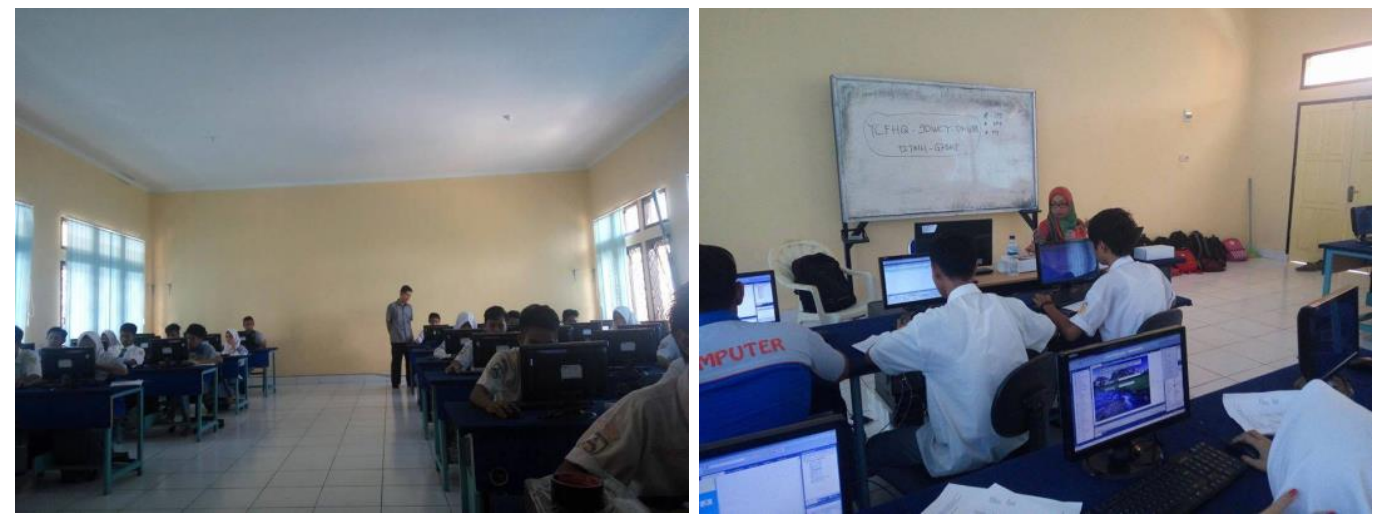

Gambar 2. Pelaksanaan kegiatan pelatihan (sesi praktik) 


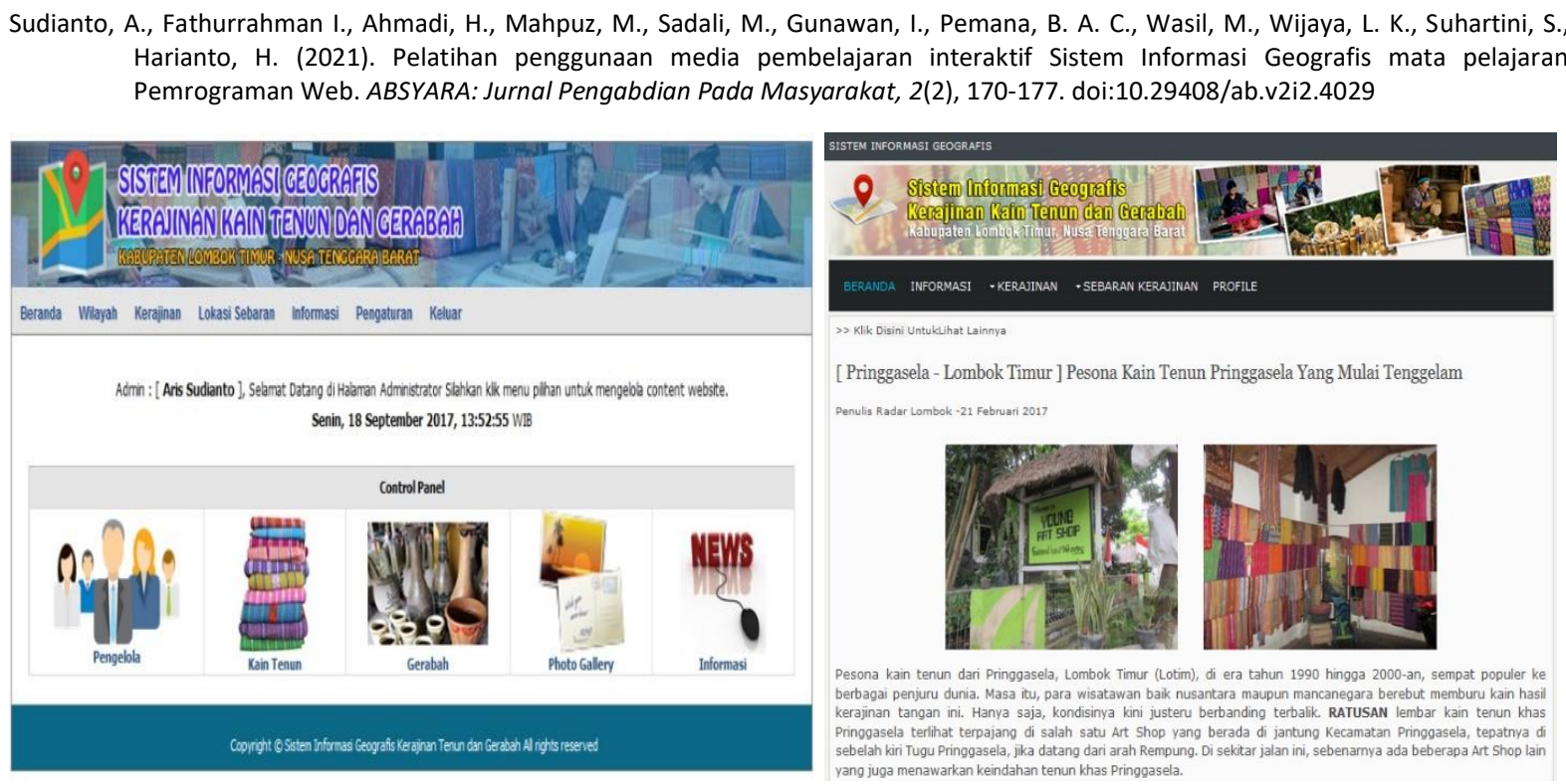

Gambar 4. Contoh hasil tampilan aplikasi yang dibuat oleh siswa

\section{PEMBAHASAN}

Melalui kegiatan ini secara signifikan mampu menambah kemampuan siswa dalam mengembangkan suatu web dinamis. Selain itu pentingnya hubungan dan kerja sama yang berkelanjutan dengan mitra juga merupakan manfaat yang dapat diambil dari kegiatan ini. Mitra juga mengharapkan kegiatan seperti ini terus dilakukan mengingat perkembangan kemampuan siswa yang didapatkan meningkat. Web merupakan sekumpulan halaman yang dapat diakses melalui jaringan internet (Sudianto \& Ahmadi, 2020; Sudianto \& Sugiantara, 2020). Banyak contoh yang dapat ditiru oleh siswa sebagai bahan latihan penunjang kompetensi, terutama berbasis web. Aplikasi web untuk pemetaan merupakan suatu model sistem yang dapat digunakan sebagai wadah untuk mencari suatu lokasi secara cepat dengan hasil yang tepat (Sudianto, 2018). PKM ini bernilai positif dikarenakan besarnya manfaatnya yang didapatkan, terutama bagi siswa SMK tingkat akhir. Bagi siswa yang akan melaksanakan uji kompetensi untuk bisa lulus di bidang kompetensi yang diambil yaitu bidang rekayasa perangkat lunak menjadi sangat terbantu dan juga siswa dapat melihat hasil nyata dan mengetahui seperti apa sebenarnya aplikasi yang mereka pelajari selama ini, hal ini senada dengan temuan dari Putra, dkk. (2020) yang menyatakan bahwa melaui pelatihan secara berkelanjutan, dapat meningkatkan hasil uji Kompetensi siswa SMK.

\section{SIMPULAN}

Dalam pelaksanaan PKM ini dapat disimpulkan berjalan dengan baik dan sesuai dengan harapan, yang ditandai dengan keberhasilan siswa - siswi jurusan Rekayasa Perangkat Lunak dalam mempraktikkan pemanfaatan teknologi dalam kegiatan pembuatan aplikasi inventaris barang berbasis WEB, walaupun masih secara sederhana.

\section{PERNYATAAN PENULIS}

Artikel ini tidak pernah dimuat dalam jurnal pengabdian maupun jurnal penelitian sebelumnya. 
Sudianto, A., Fathurrahman I., Ahmadi, H., Mahpuz, M., Sadali, M., Gunawan, I., Pemana, B. A. C., Wasil, M., Wijaya, L. K., Suhartini, S., Harianto, H. (2021). Pelatihan penggunaan media pembelajaran interaktif Sistem Informasi Geografis mata pelajaran Pemrograman Web. ABSYARA: Jurnal Pengabdian Pada Masyarakat, 2(2), 170-177. doi:10.29408/ab.v2i2.4029

\section{DAFTAR PUSTAKA}

Chang, K. T. (2016). Geographic information system. International Encyclopedia of Geography: People, the Earth, Environment and Technology: People, the Earth, Environment and Technology, 1-9.

Kholisho, Y. N., Arianti, B. D. D., Jamaluddin, J., Wirasasmita, R. H., Ismatulloh, K., Uska, M. Z., \& Fathoni, A. (2021). Pelatihan pembuatan dan editing video bagi guru SD untuk menghadapi Era Industri 4.0. ABSYARA: Jurnal Pengabdian Pada Masyarakat, 2(1), 119-127.

Okan, E. R. A. Y. (2012). Application of geographic information system (GIS) in education. Journal of Technical Science and Technologies, 53-58.

Putra, Y. K., Sadali, M., Fathurrahman, F., \& Mahpuz, M. (2020). Pelatihan uji kompetensi keahlian siswa sekolah kejuruan menggunakan metode Participatory Learning and Action (PLA). ABSYARA: Jurnal Pengabdian Pada Masyarakat, 1(2), 80-86.

Setiadi, I. M. D., Piarsa, I. N., Made, N., \& Marini, I. (2015). Sistem Informasi Geografis Pemetaan Tingkat Pertumbuhan Penduduk Berbasis Web. vol, 3, 180-189.

Sudianto, A. (2018). Penerapan Website Sebagai Sarana Promosi Wisata Budaya pada Kabupaten Lombok Timur. Infotek: Jurnal Informatika dan Teknologi, 1(1), 11-17.

Sudianto, A., \& Ahmadi, H. (2020). Rancang Bangun Sistem Informasi Penjualan Sparepart Motor Pada Bengkel Vinensi Motor Berbasis Web Guna Meningkatkan Penjualan dan Promosi Produk Pendahuluan Vinensi sepeda motor motor merupakan yang toko cukup kebutuhan suku cadang motor juga dibutuhkan s. Infotek J. Inform. dan Teknol, 3(2), 3239.

Sudianto, A., \& Sadali, M. (2018). Penerapan Sistem Informasi Geografis (GIS) dalam Pemetaan Kerajinan Kain Tenun dan Gerabah untuk Meningkatkan Potensi Kerajinan di Kabupaten Lombok Timur. Infotek: Jurnal Informatika dan Teknologi, 1(2), 71-78.

Sudianto, A., \& Samsu, L. M. (2019). Penerapan Media Pembelajaran Interaktif Pelajaran Bahasa Indonesia Berbasis Android Untuk Kelas Vii Madrasah Tsanawiyah Nahdlatul Wathan Ketangga Sebagai Upaya Untuk Peningkatkan Minat Belajar Siswa. Infotek: Jurnal Informatika dan Teknologi, 2(2), 53-60.

Sudianto, A., \& Sugiantara, J. (2020, May). Website as Foundation Information Media under the auspices of Nahdlatul Wathan. In Journal of Physics: Conference Series (Vol. 1539, No. 1, p. 012024). IOP Publishing.

Sudianto, A., Ida, N., \& Wijaya, L. K. (2020). Penerapan Sistem Informasi Geografis Untuk Pemetaan Bengkel Tambal Ban di Kecamatan Selong Kabupaten Lombok Timur. Infotek: Jurnal Informatika dan Teknologi, 3(1), 51-57.

Sudianto, A., Wasil, M., \& Mahpuz, M. (2021). Penerapan Sistem Informasi Geografis dalam Pemetaan Sebaran Kasus Gizi Buruk. Infotek: Jurnal Informatika dan Teknologi, 4(2), 142-150.

Suhartini, S., Sudianto, A., Gunawan, I., Permana, B. A. C., Ahmadi, H., Fathurrahman, I., ... \& Nurhidayati, N. (2021). Pembinaan kewirausahaan berbasis teknologi untuk 
Sudianto, A., Fathurrahman I., Ahmadi, H., Mahpuz, M., Sadali, M., Gunawan, I., Pemana, B. A. C., Wasil, M., Wijaya, L. K., Suhartini, S., Harianto, H. (2021). Pelatihan penggunaan media pembelajaran interaktif Sistem Informasi Geografis mata pelajaran Pemrograman Web. ABSYARA: Jurnal Pengabdian Pada Masyarakat, 2(2), 170-177. doi:10.29408/ab.v2i2.4029

mengembangkan jiwa Technopreneurship. ABSYARA: Jurnal Pengabdian Pada Masyarakat, 2(1), 1-7.

Wulandari, M. S., Noveandini, R., \& Sutarno, S. Digitalisasi Pemetaan UKM Tenun Garut Berbasis Sistem Informasi Geografis sebagai Media Komunikasi dan Pemasaran Produk Lokal. In Seminar Nasional Multi Disiplin Ilmu Unisbank 2015. Stikubank University. 